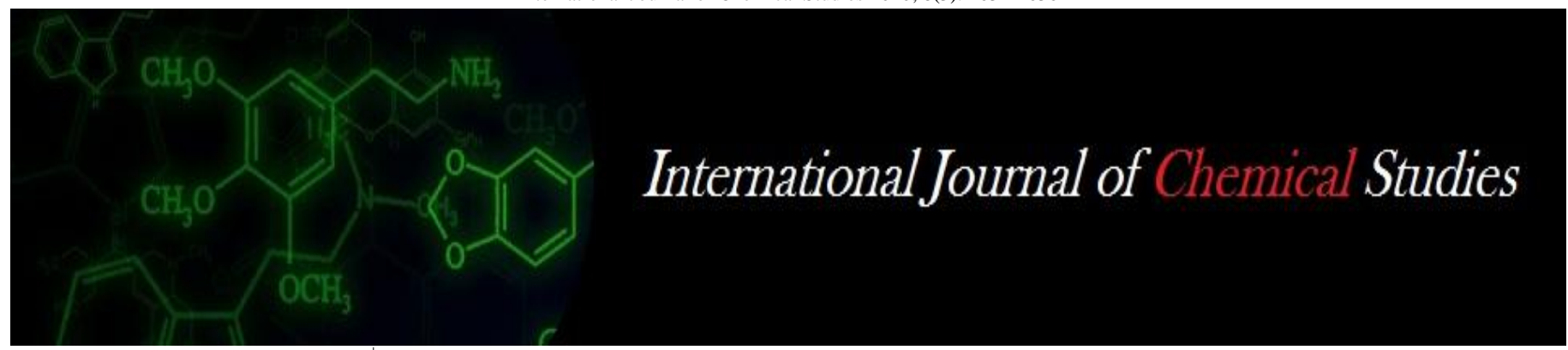

P-ISSN: 2349_8528

E-ISSN: 2321-4902

www.chemijournal.com

IJCS 2020; 8(3): 1634-1636

(C) 2020 IJCS

Received: 03-03-2020

Accepted: 06-04-2020

Uday Partap Singh

Asha Bhagwan Bax Singh P.G.

Collage, Ayodhya, Uttar

Pradesh, India

Raj Partap Singh

A.N.D.U.A.T., Kumarganj,

Ayodhya, Uttar Pradesh, India

Dr. Chandra Shekhar

Associate Professor, Ag.

Chemistry and Soil Science,

Gochar Mahavidyalaya, Rampur

Maniharan, Uttar Pradesh, India

Corresponding Author:

Uday Partap Singh

Asha Bhagwan Bax Singh P.G.

Collage, Ayodhya, Uttar

Pradesh, India

\section{Wilt disease management of pigeonpea caused by Fusarium oxysporum $f$. sp. udu of Eastern U.P.}

\author{
Uday Partap Singh, Raj Partap Singh and Dr. Chandra Shekhar
}

DOI: https://doi.org/10.22271/chemi.2020.v8.i3v.9430

\begin{abstract}
Wilt disease (Fusarium oxysporum f. sp. udum) is one of the most destructive soil-borne diseases of Pigeon pea. Field experiments were conducted at supervision of Asha Bhagwan Bax Singh P.G. College Ayodhya, during Kharif seasons of 2017 and 2018 in the farmer's field of Ayodhya and Ambedkarnager district of Uttar Pradesh, to find out different integrated management levels of control schedule for pigeon pea wilt disease. All treatments had a significant effect on disease incidence, seed yield and disease index in both the consecutive years of experimentation. Nine Seed treatment combinations viz. T1- Trichoderma viride alone @ 12g/kg seed, T2- Thiram + Carbendazim + Trichoderma viride + Rhizobium @ 13 g/kg, T3- Thiram + Carbendazim+ Trichoderma viride + Rhizobium + Soil application of Trichoderma viride @ $10 \mathrm{~g} / \mathrm{kg}$, T4- Carbendazim $50 \%$ WP (ST) @ $5.0 \mathrm{~g} / \mathrm{kg}$, T5- Carbendazim $25 \%$ WP + mancozeb50\%WP (ST) @ 3.0 g/kg, T6- Neem seed cake (SA) @ 5.0q/ha.. T7- Castor seed cake (SA) @ 6.0q/ha, T8- neem seed cake (SA) + [carbendazim $25 \% \mathrm{WP}+$ mancozeb $50 \% \mathrm{WP}$ ] (ST) + azoxystrobin 23 EC (SD) + Soil application of Trichoderma viride @ $20 \mathrm{~kg} / \mathrm{ha}+1 \mathrm{~kg} / \mathrm{ha}+3 \mathrm{~g} / \mathrm{kg}$ seed $+12 \mathrm{~g} / \mathrm{kg}$ seed $+12 \mathrm{~g}$ and T9- untreated control were evaluated against wilt disease of pigeon pea on the popular variety Bahar. T8- neem seed cake (SA)+ carbendazim $25 \% \mathrm{WP}+$ mancozeb $50 \% \mathrm{WP}(\mathrm{ST})+$ azoxystrobin 23 EC (SD) + Soil application of Trichoderma viride @ $20 \mathrm{~kg} / \mathrm{ha}+1 \mathrm{~kg} / \mathrm{ha}+3 \mathrm{~g} / \mathrm{kg}$ seed $+12 \mathrm{~g} / \mathrm{kg}$ seed $+12 \mathrm{~g}$ was found most effective with minimum wilt incidence 2017 and $2018(3.40 \%$ and $5.50 \%$ ), reduction over control (\%) $93.99 \& 90.86$ and disease index $61.76 \& 61.48 \%$ and recorded maximum yield 2017 and 2018 (2160 and $2100 \mathrm{~kg} / \mathrm{ha}$ ), respectively followed by T3- Thiram + Carbendazim + Trichoderma viride + Rhizobium + Soil application of Trichoderma viride @ $10 \mathrm{~g} / \mathrm{kg}$, 10.90 and $11.60 \%$ wilt incidence, reduction over control $(\%) 80.74 \& 80.73$ and disease index $55.17 \&$ $55.26 \%$ with yield $\mathrm{kg} / \mathrm{ha}$ was $1740 \mathrm{~kg} / \mathrm{ha}$ and $1860 \mathrm{~kg} / \mathrm{ha}$.
\end{abstract}

Keywords: Pigeon pea wilt, Fusarium oxysporum f. sp. udum, Trichoderma viride

\section{Introduction}

Pigeon pea are the major pulse crops grown in India. These occupy more than 50 percent of total area under pulses, and contribute 60 percent to total pulses production. The average productivity of chickpea and pigeon pea is about $800 \mathrm{~kg} / \mathrm{ha}$ and $750 \mathrm{~kg} / \mathrm{ha}$, respectively, which is much lower than their potential yields. A number of factors limit achieving this potential, biotic constraints are the most important. Some state leading centre in terms of productivity of highest Gujarat (1059 kg/ha) next Uttar Pradesh $916 \mathrm{k} / \mathrm{ha}$ and third rank of Madhya Pradesh $780 \mathrm{~kg} / \mathrm{ha}$. Whenever National productivity of this crop is quite low $780 \mathrm{~kg} / \mathrm{ha}$ to varietal potentional. India has 3.90 mha ( $80 \%$ of world acreage) with a total production and productivity of $2.89 \mathrm{mt}$ (79\% of world production) and around $750 \mathrm{~kg} / \mathrm{ha}$, respectively (http://www.faostat.fao.org). The productivity is $150 \mathrm{~kg} / \mathrm{ha}$ lower compared to global average. In order to make the nation self sufficient in pulses productivity levels of pulses need to be increased substantially from $560 \mathrm{~kg}$ ha-1 to $1,200 \mathrm{~kg}$ ha-1 by 2020 . In spite of many interventions, per capita nutrition supply in India among the lowest in the world (OECD, 2015, Goda et al. 2013). Among the biotic stresses, diseases are the major yield limiting factors causing a yield loss of about 8-10 percent and Rs 1500 crores per year. Pigeonpea is affected by more than a hundred pathogens (Nene et al., 1981) ${ }^{[6]}$. The major diseases affecting pigeon pea are wilt (Fusarium udum), sterility mosaic (Pigeon pea sterility mosaic virus - PSMV) and Phytophthora blight (P. drechslerif. sp. cajani). Under specific situations, Alternaria blight (A. alternata, A. tenuissima), Cercospora leaf sport (Cercospora spp.) also assume significant importance. Losses due to wilt and sterility mosaic in pigeon pea have been estimated to be 
about 302 thousand tonnes, based on the prevalence status of these diseases during 1975 to 1980 (Kannaiyan et al., 1984) [5]. The grain loss due to chickpea wilt and root rot has been estimated around 10 percent (Lal et al., 1992; Singh and Dahiya, 1973) ${ }^{[2,3]}$, In recent years, a good progress has been made in the development of wilt/ root rot resistant varieties in chickpea and pigeon pea (Dhar and Chaudhary, 2001) ${ }^{[4]}$. These have brought some stability in production in disease endemic areas. However, to further enhance the efficiency of these varieties, there is a need to provide other management options. Wilt resistant varieties of pigeonpea for northeastern plains (Uttar Pradesh, Bihar and West Bengal), which occupy a sizeable area under the crop, are not yet available. Incidentally, only a few of them cause economic losses (Kannaiyan et al., 1984) ${ }^{[5]}$ and the distribution of the most important diseases is geographically restricted, among which wilt caused by Fusarium udum is a serious problem in the production of pigeonpea. The incidence of infection ranges from $3-94 \%$ in the field. The disease can attack at any stage of the plant, but the highest mortality occurs at the flowering and podding stage. The wilt caused by Fusarium udum is one of the most serious and oldest known diseases (Butler, 1906) and is known to cause heavy losses every year in India (Kannaiyan et al., 1981) ${ }^{[6]}$. Fusarium wilt (Fusarium udum) is a soil-borne disease. Fusarium wilt is the most important disease of pigeonpea in India resulting in yield losses up to 67 per cent at maturity and 100 per cent in case of infection at pre-pod stage (Kannaiyan and Nene, 1981) ${ }^{[6]}$. The Fusarium wilt in pigeonpea was first reported from Bihar by Butler (1910). The similar finding of wilt disease of pigeon pea Karimi R et al., 2012, ${ }^{[8]}$ Kumar, S. and Upadhyay, J. P. 2015 [9], Mahesh et al., $2010^{[10]}$, Pawar S. V et al., $2013^{[11]}$ and Prasad, P. S. et al., $2012_{\text {[12], }}$

\section{Materials and Methods}

The experiment were carried out at various parts of different villages in Ayodhya and Ambedkar nager of Uttar Pradesh viz. Wazidpur, Sarai Khawaja Urf Darbanipur, Chand Pur, Mainpur, Olandganj, and Muradganj district of were evaluated against wilt disease of pigeon pea the popular variety Bahar. Experiment was laid out in one village one replication. Most popular variety used was Bahar and the gross plot size was 200 sq. metres and all packages of practices were followed for conducting the experiment. This experiment was laid out in randomized block design with four replications ( 2 Ayodhya and 2 Ambedkar nager). One village one replication, the soil of the farmers' field was sandy loam in texture, neutral in reaction and had low nitrogen and medium phosphorus and potassium contents. To evaluate the efficacy of new molecules/chemicals against wilt, were tested. Eight treatment Seed combinations viz. T1- Trichoderma viride alone @ 12g/kg seed, T2- Thiram + Carbendazim + Trichoderma viride + Rhizobium @ 13 g /kg, T3- Thiram + Carbendazim+ Trichoderma viride + Rhizobium + Soil application of Trichoderma viride @ $10 \mathrm{~g} / \mathrm{kg}$, T4Carbendazim 50 \% WP (ST) @ $5.0 \mathrm{~g} / \mathrm{kg}$, T5- Carbendazim 25 $\% \mathrm{WP}+$ mancozeb50 \% WP (ST) @ $3.0 \mathrm{~g} / \mathrm{kg}$, T6- Neem seed cake (SA) @ 5.0q/ha.. T7- Castor seed cake (SA) @ 6.0q/ha, T8- neem seed cake (SA)+ [carbendazim $25 \%$ WP + mancozeb $50 \% \mathrm{WP}$ (ST) + azoxystrobin $23 \mathrm{EC}(\mathrm{SD})+$ Soil application of Trichoderma viride @ $20 \mathrm{~kg} / \mathrm{ha}+1 \mathrm{~kg} / \mathrm{ha}+3$ $\mathrm{g} / \mathrm{kg}$ seed $+12 \mathrm{~g} / \mathrm{kg}$ seed $+12 \mathrm{~g}$ and T9- untreated control. The crop was sown manually after the onset of monsoon with a spacing of $60 \mathrm{~cm} \times 15 \mathrm{~cm}$ using a certified seed with a seed rate of $20 \mathrm{~kg} / \mathrm{ha}$. To prevent the crop from the soil and seed- borne diseases, the seeds were treated with a combination of different fungicide, bioagents, and culture as per the treatments. The crop was fertilized with 20,60 and $30 \mathrm{~kg} \mathrm{~N}$, $\mathrm{P} 2 \mathrm{O} 5$ and $\mathrm{K} 2 \mathrm{O} / \mathrm{ha}$, respectively. The harvesting was done manually with the help of sickle when the crop attained full maturity. The produce of a square meter from four randomly selected of each plot was tied into a bundle and allowed to sun drying in respective plots. The harvested bundles were weighed with the help of balance and transported to the threshing floor. Threshing of the produce of each plot was done separately by beating with wooden sticks; the seeds were then cleaned manually and weighed. Wilt incidence percent (WI \%) is calculated at $60 \mathrm{DAS}$ and $150 \mathrm{DAS}$, with the help of the following formulae:

Wilt incidence (WI) \%=Number of plants infected by wilt disease/Total number of plants observed X 100

Seed yield of the net plot was noted down, after threshing, winnowing, and drying and calculated in $\mathrm{q}$ ha-1. Disease index indicates the reduction in yield of crop due to disease attack and is expressed in percent by using formulae:

Disease index $(\%)=$ Yield from treated plot-yield from the untreated plot/ Yield from treated plot X 100

\section{Results and Discussion}

There was significant difference among the treatments in wilt disease severity and yield. The data on different disease parameters is summarised in table 1. Different integrated management levels of control schedule for pigeon pea wilt disease had a significant effect on disease incidence percent, seed yield, and disease index in both the consecutive year of experimentation. Treated with T8- neem seed cake (SA)+ carbendazim $25 \% \mathrm{WP}+$ mancozeb $50 \% \mathrm{WP}(\mathrm{ST})+$ azoxystrobin 23 EC (SD) + Soil application of Trichoderma viride@ $20 \mathrm{~kg} / \mathrm{ha}+1 \mathrm{~kg} / \mathrm{ha}+3 \mathrm{~g} / \mathrm{kg}$ seed $+12 \mathrm{~g} / \mathrm{kg}$ seed $+12 \mathrm{~g}$ was found best in checking the disease incidence 3.40 and 5.50, reduction over control (\%) $93.99 \& 90.86$. and disease index 61.76 and $61.48 \%$ year of 2017 and 2018 respectively and the better grain yield 2040 and $2160 \mathrm{~kg} / \mathrm{ha}$ was recorded. While incidence of wilt disease had gone to the extent of 56.60 and 60.20 respectively in untreated plots. In check plots reduced grain yield was recorded (780 and 832 $\mathrm{kg} / \mathrm{ha}$ ). The plot treated with had also shown good response with T3- Thiram + Carbendazim+ Trichoderma viride + Rhizobium + Soil application of Trichoderma viride @ $10 \mathrm{~g} / \mathrm{kg} 10.90$ and $23.0 \%$ disease incidence, reduction over control (\%) $80.74 \& 80.73$ and disease index 55.17 and $55.26 \%$, along with good grain yield 1740 and $1860 \mathrm{~kg} / \mathrm{ha}$. was recorded. In treatment T2- Thiram + Carbendazim + Trichoderma viride + Rhizobium @ 13 g/kg, disease incidence 15.60, reduction over control (\%) 72.43 \& 73.23 and disease index 51.25, $51.34 \%$ year of 2017 and 2018 respectively and the better grain yield 1600 and $1710 \mathrm{~kg} / \mathrm{ha}$ was recorded. T1- Trichoderma viride alone @ 12 g/kg showed good response 16.20 and 17.24 disease incidence $\%$ reduction over control (\%) $71.38 \& 71.36$ was observed and disease index 46.68 and 45.33 along with 1463 and 1522 $\mathrm{kg} / \mathrm{ha}$. grain yield. In the plot treated with T5-Carbendazim $25 \%$ WP + mancozeb50 \% WP (ST) @ 3.0 g/ kg 20.10, $19.60 \%$ disease incidence a reduction over control (\%) 64.48 $\& 67.44$ and disease index 47.29, $45.69 \%$ along with 1480 , $1532 \mathrm{~kg} / \mathrm{ha}$ grain yield. The plot treated with T4- Carbendazim 50 \% WP (ST) @ 5.0 g/kg 20.24, 26.77\%, disease incidence reduction over control (\%) 64.24, 55.23 and disease index $48.06,45.44$, with yield $1502 \& 1525 \mathrm{~kg} / \mathrm{ha}$ was recorded. The plot treated with T6- Neem seed cake (SA) @ 5q/ha. 
$22.80,23.70 \%$, disease incidence, reduction over control (\%) 59.71, 60.63 and disease index 40.45, 40.14 with yield 1390, $1350 \mathrm{~kg} / \mathrm{ha}$ was recorded. The plot treated with T7- Castor seed cake (SA)) @ 6q/ha. 24.60, 23.90\%, disease incidence, reduction over control (\%) 56.54, 60.29 and disease index $35.00,34.74$ with yield $1200,1275 \mathrm{~kg} / \mathrm{ha}$ was recorded.

All these treatments were found effective in checking in disease incidence over untreated control and increased the grain yield of pigeon pea at various extent. neem seed cake (SA)+ carbendazim $25 \% \mathrm{WP}+$ mancozeb $50 \% \mathrm{WP}(\mathrm{ST})+$ azoxystrobin 23 EC (SD) + Soil application of Trichoderma viride was found best in the average of disease incidence 4.45, reduction over control (\%) 92.43. and disease index $61.62 \%$ respectively and grain yield $2100 \mathrm{~kg} / \mathrm{ha}$ was recorded. followed by Thiram + Carbendazim + Trichoderma viride + Rhizobium + Soil application of Trichoderma viride @ $10 \mathrm{~g} / \mathrm{kg} 10.90$ and $23.0 \%$ disease incidence, reduction over control (\%) 80.74 \& 80.73 and disease index 55.17 and $55.26 \%$, along with good grain yield 1740 and $1860 \mathrm{~kg} / \mathrm{ha}$. was recorded, minimization of disease incidence may be one of the possible reasons for enhancement of grain yield.

Table 1: Efficacy of various treatments integration against wilt (F. udum) incidence and seed yield in pigeon pea during Kharif 2017-18 and 2018-19

\begin{tabular}{|c|c|c|c|c|c|c|c|c|c|c|c|c|c|c|}
\hline \multirow[t]{2}{*}{$\begin{array}{l}\text { SI. } \\
\text { No. } \\
\end{array}$} & \multirow[t]{2}{*}{ Treatments } & \multirow[t]{2}{*}{ Dose/kg } & \multicolumn{3}{|c|}{ Wilt incidence (\%) } & \multicolumn{3}{|c|}{$\begin{array}{l}\text { Reduction over } \\
\text { control }(\%)\end{array}$} & \multicolumn{3}{|c|}{$\begin{array}{c}\text { Disease } \\
\text { index (\%) }\end{array}$} & \multicolumn{3}{|c|}{ Yield kg/ha. } \\
\hline & & & 2017 & 2018 & Mean & 2017 & 2018 & Mean & 2017 & 2018 & Mean & 2017 & 2018 & Mean \\
\hline T1- & Trichoderma viride alone & $12 \mathrm{~g}$ & 16.20 & 17.24 & 16.72 & 71.38 & 71.36 & 71.37 & 46.68 & 45.33 & 46.01 & 1463 & 1522 & 1493 \\
\hline T2- & $\begin{array}{c}\text { Thiram + Carbendazim + Trichoderma } \\
\text { viride + Rhizobium }\end{array}$ & $13 \mathrm{~g}$ & 15.60 & 16.11 & 15.86 & 72.43 & 73.23 & 72.83 & 51.25 & 51.34 & 51.30 & 1600 & 1710 & 1655 \\
\hline T3- & $\begin{array}{c}\text { Thiram + Carbendazim + Trichoderma } \\
\text { viride + Rhizobium + Soil application } \\
\text { of Trichoderma viride }\end{array}$ & $10 \mathrm{~g}$ & 10.90 & 11.60 & 11.25 & 80.74 & 80.73 & 80.74 & 55.17 & 55.26 & 55.22 & 1740 & 1860 & 1800 \\
\hline T4- & Carbendazim 50\% WP (ST) & $5 \mathrm{~g}$ & 20.24 & 26.77 & 23.51 & 64.24 & 55.53 & 59.89 & 48.06 & 45.44 & 46.75 & 1502 & 1525 & 1514 \\
\hline T5- & $\begin{array}{c}\text { Carbendazim } 25 \% \mathrm{WP}+\text { mancozeb50 } \\
\% \mathrm{WP}(\mathrm{ST})\end{array}$ & $3 \mathrm{~g}$ & 20.10 & 19.60 & 19.85 & 64.48 & 67.44 & 65.96 & 47.29 & 45.69 & 46.49 & 1480 & 1532 & 1506 \\
\hline T6- & Neem seed cake (SA) & 5q/ha. & 22.80 & 23.70 & 23.25 & 59.71 & 60.63 & 60.17 & 40.45 & 40.14 & 40.30 & 1310 & 1390 & 1350 \\
\hline T7- & Castor seed cake (SA) & $6 \mathrm{q} / \mathrm{ha}$ & 24.60 & 23.90 & 24.25 & 56.54 & 60.29 & 58.42 & 35.00 & 34.74 & 34.87 & 1200 & 1275 & 1238 \\
\hline T8- & $\begin{array}{c}\text { neem seed cake (SA)+ [carbendazim } \\
25 \% \mathrm{WP}+\text { mancozeb } 50 \% \mathrm{WP} \text { (ST) } \\
\text { + azoxystrobin } 23 \mathrm{EC}(\mathrm{SD})+\text { Soil } \\
\text { application of Trichoderma viride }\end{array}$ & $\begin{array}{l}20 \mathrm{~kg} / \mathrm{ha}+1 \mathrm{~kg} / \\
\mathrm{ha}+3 \mathrm{~g} / \mathrm{kg} \text { seed } \\
+12 \mathrm{~g} / \mathrm{kg} \text { seed } \\
+12 \mathrm{~g}\end{array}$ & 3.40 & 5.50 & 4.45 & 93.99 & 90.86 & 92.43 & 61.76 & 61.48 & 61.62 & 2040 & 2160 & 2100 \\
\hline T9- & Untreated control & & 56.60 & 60.20 & 58.40 & - & - & - & - & - & - & 780 & 832 & 806 \\
\hline
\end{tabular}

\section{References}

1. Kannayian J, Nene YL, Reddy MV, Ryan JG, Raju TN. Prevalence of pigeonpea diseases and associated crop losses in Asia, Africa and the America. Tropical Pest Management. 1984; 30(1):62-71.

2. Lal SS, Yadava CP, Sachan JN. Assessment of pod borer damage in pigeonpea in different agro-ecological zones of Uttar Pradesh. Indian Journal of Pulses Research. 1992; 5(2):172-178.

3. Singh KB, Dahiya BS. Breeding for wilt resistance in chickpea. In: Symposium on Wilt Problems and Breeding for Resistance in Bengal Gram. IARI, New Delhi, India, 1973, 13-14.

4. Dhar, Vishwa, Chaudhary RG. Disease resistance in pulse crops - Current status and future approaches. In: Role of resistance in intensive agriculture (Eds. S. Nagarajan and D.P. Singh). Ludhiana: Kalyani Publishers, 2001.

5. Nene YL, Kannaiyan J, Reddy MV. Pigeonpea diseases: resistance screening techniques. Information Bulletin No.9. ICRISAT, India, 1984.

6. Kannaiyan J, Nene YL, Reddy MV. Influence of wilt at different growth stages on yield loss in Pigeonpea. Tropical Pest Management. 1981; 27:141.

http://www.faostat.fao.org.

7. Gowda CL, Srinivasn S, Gaur PM, Saxena KB. Enhancing productivity and productivity of pulses in India. Climate change and sustainable food security, ICAR, New Delhi, 2013, 145-159.

8. Karimi R, James OO, Silim SN. Importance and management of Fusarium wilt (Fusarium udum Butler) of pigeonpea. Inter. J Agronomy Agril. Res. 2012; 2(1):114.
9. Kumar S, Upadhyay JP. Development and validation of Integrated Disease Management module for Management of pigeonpea wilt caused by Fusarium udum. Indian J. Pl. Protec. 2015; 43(4):493-497.

10. Mahesh M, Saifulla M, Prasad PS, Sreenivasa S. Studies on cultural variability of Fusarium udum isolates in India. Inter. J Sci. Nature. 2010; 1(2):219-225.

11. Pawar SV, Deshpande GD, Dhutraj DN, Dey U. Survey of pigeonpea wilt disease in Marathwada region of Maharashtra state. A Quarterly J. life Sci. 2013; 10(1):175-176.

12. Prasad PS, Saifulla M, Mallikarjuna N, Thimmegowda PR, Lakshmipathy RN. Integrated disease management of Pigeonpea wilt Fusarium udum (Butler). Madras Agric. J. 2012; 99(10):811-814. 